\title{
SANEAMENTO BÁSICO E ASSENTAMENTO RURAL - UM ESTUDO DE CASO DO ASSENTAMENTO ZUMBI DOS PALMARES, RJ
}

\author{
Giselle Fonseca Soares \\ Especialista em Ciências Ambientais e da Saúde \\ Companhia Estadual de Águas e Esgotos - CEDAE \\ gisa_fsoares@yahoo.com.br \\ Lucíola Santos Lannes* \\ Doutora em Ciências Naturais \\ Universidade Estadual Paulista - UNESP Faculdade de Engenharia de Ilha Solteira - FEIS \\ luciola.lannes@bio.feis.unesp.br
}

\section{RESUMO}

A percepção ambiental e o saneamento básico apresentam grande relevância com relação aos pressupostos básicos de implementação dos projetos de assentamento de reforma agrária, devido se apresentarem como bases para a promoção de cidadania e cumprimento da função social da terra. Este estudo tem como objetivo realizar um levantamento da condição situacional dos moradores do Assentamento Zumbi dos Palmares acerca de percepção ambiental e saneamento básico, além de verificar a qualidade bacteriológica do aqüífero freático do assentamento. Foram encontrados em 100\% das amostras índices elevadíssimos de coliformes totais e presença de Escherichia coli em $91 \%$ das amostras analisadas. A maioria das famílias assentadas utiliza poço cacimba como meio para obtenção de água para consumo, sendo esta utilizada sem prévio tratamento e alocam o esgoto em fossas sépticas. Os assentados quase não têm informações sobre doenças potencialmente transmitidas pela água e apresentam uma grande falta de conhecimento acerca de saneamento básico e conservação ambiental.

Palavras-chave: Assentamento rural; Percepção ambiental; Qualidade da água; Saneamento.

\begin{abstract}
The environmental perception and the basic sanitation related to the management of land distribution in Brazil are very important concerning to the implementation of land settlements, mainly because they guarantee the citizenship and satisfy the social function of the land. This study aims to verify the sanitation conditions of the inhabitants of the Zumbi dos Palmares landless rural settlement, besides their perception about it. For that we did an analysis of environmental perception together with determinations of coliforms in water-table wells. Very high amounts of total and fecal coliforms were found. The results show that mostly of the families settled obtain their consumed water through domestic water-table wells with no previous treatment and dispose their sewage in septic tanks. Besides, they have very scarce information about diseases transmitted by water and present a great lack of information concerning to basic sanitation and environmental conservation.
\end{abstract}

Keywords: Environmental perception; Rural settlement; Sanitation; Water quality

\section{INTRODUÇÃO E JUSTIFICATIVA}

O cenário que envolve a questão da reforma agrária no município de Campos dos Goytacazes e São Francisco de Itabapoana, mais especificamente o Assentamento Zumbi dos Palmares, pertence a um importante conjunto de modificações ocorridas no espaço agrário fluminense. Segundo Gonçalves (2004), "a década de 90 do século XX foi marcada por significativos rearranjos territoriais, consequiência do processo 
de reestruturação econômica no qual se tem fechamento de algumas e expansão de outras usinas de cana-deaçúcar e a territorialização com a interiorização dos trabalhadores sem terra". Nesse contexto, a questão da percepção ambiental e do saneamento básico relacionados à reforma agrária, assim como o tipo de concepção dos assentados com relação ao desenvolvimento sustentável, tornam-se fatores de grande relevância diante do uso dos recursos naturais da região - a forma de manejo da terra, dos recursos hídricos, e junto a ela a possibilidade de sucessos ou falhas tanto para os assentados quanto para o ambiente.

O saneamento básico e a qualidade da água são determinantes da saúde de qualquer comunidade humana, constituindo-se assim fatores fundamentais para a garantia da qualidade de vida das pessoas. Segundo dados da Organização Mundial de Saúde (OMS), 80\% das doenças que ocorrem nos países em desenvolvimento são propiciadas pela contaminação da água. Sabe-se também, que a cada ano, 15 milhões de crianças de 0 a 5 anos morrem direta ou indiretamente devido à falta ou deficiência dos sistemas de abastecimento de águas e esgotos (CETESB, 1996). A falta de abastecimento de água potável é responsável pela transmissão de diversas doenças, como febre tifóide, cólera e desinteria bacilar. A zona rural geralmente se apresenta como local sem água encanada, sendo comum o abastecimento através de poços ou cacimbas, havendo, portanto, a necessidade de se respeitar regras básicas durante o processo de construção destes, de forma a garantir a potabilidade da água a ser consumida.

A falta de ações efetivas no sentido de se proteger os mananciais, assim como a ausência de uma política de saneamento que atenda às áreas periféricas fazem com que a água seja uma variável que passa a oscilar entre necessidade primordial à saúde e veículo de transmissão de agentes de doenças infecciosas e parasitárias. Definir, por exemplo, qual é a melhor política de saneamento para uma comunidade envolverá, portanto, o levantamento de informações teórico-práticas pertinentes ao tema visando pormenorizar a relação saneamento e ambiente, com o intuito de investigar a visão dos assentados com respeito à conservação e utilização dos mananciais, tanto superficiais quanto subterrâneos, pertinentes a toda a área do assentamento. Vale ressaltar que na época da implantação do Assentamento Zumbi dos Palmares o projeto de assentamento elaborado pelo INCRA definiu alguns lotes adentrando áreas de preservação de lagoas e de fragmentos de floresta de Mata Atlântica.

Como pressuposto pelo INCRA, pode-se visualizar que o ato isolado de assentar famílias não seja suficientemente significativo aos objetivos da reforma agrária, não bastando apenas dispor as pessoas na terra sem estruturar a situação dos indivíduos no que tange as questões básicas de sobrevivência. Para tal, faz-se necessário dotar os assentados de instrumentos que visem à melhoria das condições de vida da comunidade, tendo como pano de fundo ações voltadas para o efetivo alcance das metas estabelecidas.

O INCRA na implantação dos assentamentos de reforma agrária deverá: garantir a efetiva participação dos assentamentos nas atividades de planejamento e execução das ações relativas ao desenvolvimento territorial; aportar os recursos orçamentários e financeiros preferencialmente de forma global e não fragmentada; garantir a assistência técnica desde o início da implantação do assentamento, de forma a definir o modelo de exploração da área, organização espacial, moradia, infra-estrutura básica, licenciamento ambiental e serviços sociais; qualificar e adequar as normas ambientais como ação e condição necessária à implantação do Plano de Desenvolvimento do Assentamento - PDA, promovendo a exploração racional e sustentável da área e a melhoria de qualidade de vida dos assentados; fortalecer o processo de constituição da capacidade organizativa, com base na cooperação e no associativismo das famílias assentadas; articular e integrar as políticas públicas de assistência técnica, extensão rural, educação, saúde, cultura, eletrificação rural, saneamento básico, necessárias ao desenvolvimento do projeto de assentamento; possibilitar que as áreas reformadas sejam indutoras do desenvolvimento territorial combatendo as causas da fome e da pobreza.

\section{INSTRUÇÃO NORMATIVA/INCRA/N ${ }^{\circ}$ 15, DE 30 DE MARÇO DE 2004. (Página do INCRA na internet, www.incra.gov.br)}

Quando da implantação do Assentamento Zumbi dos Palmares, em 1997, foram desenvolvidas diversas propostas para o plano de desenvolvimento do assentamento (PDA), a partir do projeto de 
cooperação técnica entre MEPF-INCRA/FAO, onde se teve como objetivo a implementação de encaminhamentos políticos e sociais, tais como educação, transporte, alimentação e saneamento.

Entender como a comunidade assentada percebe a questão do saneamento básico e do ambiente em que vive, em especial no que tange aos recursos da região, bem como visualizar quais são suas insatisfações e expectativas diante do fato de que esta se encontra constantemente alterando o meio com intuito de sanar suas necessidades, consistem em pontos fundamentais na busca da qualidade de vida da comunidade, na conservação dos recursos naturais e na sensibilização em relação aos problemas ambientais da região.

\section{FUNDAMENTAÇÃO TEÓRICA}

\subsection{Percepção ambiental}

A área que cobre o Assentamento Zumbi dos Palmares fica situada em região composta de importantes recursos naturais, tanto no que se refere a resquícios da Mata Atlântica - matas de Bom Jesus e do Cajueiro localizadas nas imediações do Zumbi 1 e 5 respectivamente - bem como a recursos hídricos como lagoas, canais e braços de rios dentre os quais podemos destacar a Lagoa de Campelo, Lagoa da Saudade, Lagoa do Gregório e Lagoa do Jacarandá.

A avaliação de valores ecológicos, sócio-econômicos e culturais numa dada região é fator preponderante para o planejamento do uso dos recursos naturais. A relação entre reforma agrária e percepção ambiental sugere assim estreita ligação quanto à questão do planejamento do ambiente orientado para conservação e manejo dos recursos naturais. Na contextualização da reforma agrária na região de Campos dos Goytacazes e São Francisco de Itabapoana, é de grande relevância entender como a comunidade assentada percebe o ambiente em que vive, como é orientada sua ação a fim de sanar necessidades como moradia, transporte, alimentação e saneamento básico.

No que tange ao perfil dos assentados, podem ser destacados em especial dois pontos relevantes que também se apresentam intimamente ligados à percepção ambiental. O primeiro consiste na forma de chegada dos assentados para o assentamento - quase a metade dos assentados (46\%) chegou à área através do recrutamento feito pelo MST nos bairros e comunidades periféricas dos municípios de Campos dos Goytacazes e São Francisco de Itabapoana. Por outra via, cerca de 38\% dos assentados chegaram através do sistema de cadastramento do INCRA, enquanto $7 \%$ foram recrutados pelo Sindicato dos Trabalhadores Rurais de São Francisco de Itabapoana. O segundo diz respeito à origem dos assentados do Assentamento Zumbi dos Palmares em Campos dos Goytacazes - cerca de 53\% são provenientes da região urbana e periurbana desta cidade, onde muitos assentados desempenhavam atividades informais no setor de comércio e serviços, e muitos eram ex-empregados de antigas usinas que faliram. Por outro lado, apesar da maioria dos assentados não ser identificada como oriunda da região rural, pôde-se constatar que cerca de $85 \%$ declararam-se no exercício de alguma atividade relacionada com a agricultura ou pecuária antes de se tornarem assentados (ZINGA, 2004). Segundo a UNESCO, uma das dificuldades para a proteção dos ambientes naturais está na existência de diferenças nas percepções dos valores e da importância dos mesmos entre os indivíduos de culturas diferentes ou de grupos sócio-econômicos que desempenham funções distintas, no plano social, nesses ambientes.

\subsection{Reforma agrária}

Incluída no vocabulário político do país entre anos 50 e 60, a reforma agrária surgiu como bandeira política de variadas instituições, tais como o Partido Comunista, a Igreja Católica, a Comissão Econômica para a América Latina (CEPAL) e as Ligas Camponesas. Porém após o golpe militar de 1964, esta assumiu no decorrer da ditadura o status de política pública, onde foram criados sucessivos organismos governamentais (SUPRA, Inda, INCRA), que domesticaria o seu significado, ficando respaldada pelo poder público através do Estatuto da Terra (NOVAES, 1996). Concomitantemente, ela se transforma em causa de luta sindical, onde o movimento sindical dos trabalhadores rurais tomou-a como possibilidade de unificação das diversas categorias de trabalhadores rurais do país. Assim, a reforma agrária passa a significar, ao mesmo tempo, política pública que possui organismos e espaço no aparelho do Estado e bandeira central da pauta sindical e "causa civil". 
Com o surgimento da Campanha Nacional pela Reforma Agrária (década de 80), que nasce num período em que as centrais sindicais estão se formando, faz-se emergir a possibilidade de se juntar diferentes vertentes do cenário político da época tais como Contag, CUT, CNBB, CPT, OAB, que eram grupos que necessariamente não apresentavam o mesmo ideário político. O Movimento dos Trabalhadores Rurais Sem Terra (MST) nasce neste período, e com o reforço da campanha, logo se articula.

O MST apresenta-se como um dos movimentos mais contundentes e visíveis dos últimos anos. Foi desencadeado no final da década de 70 com a ocupação de duas fazendas no município de Ronda Alta/RS, sendo posteriormente, seguido por ações similares em todo país, principalmente nos estados do Paraná e São Paulo (GEHLEN, 1983).

O MST teve sua criação oficializada em 1984, durante congresso realizado Cascavel/PR, e apresenta-se organizado da seguinte forma: Coordenação Nacional, Direção Nacional, Coordenação Estadual, Coordenação Regional e Coordenações de Assentamentos e Acampamentos. Seu principal "slogan" é Ocupar, Resistir e Produzir, o qual elucida sua forma idealizada de implementação da reforma agrária, ou seja, através da ocupação forçada em terras não produtivas ou de situação indefinida. À medida que os assentados vão se estabelecendo, a preocupação com o saneamento, ambiente, e os demais aspectos hoje relacionados à ecologia adquirem importância perante a grande dificuldade em se conseguir compatibilizar desenvolvimento sustentado e equilíbrio ecológico. Temas como educação popular, alimentação, saúde, emprego e ambiente têm extrapolado a questão fundiária para dar lugar a uma análise abrangente acerca dos fatos que acompanham os processos de democratização da terra. A reforma agrária deve, portanto, ser apresentada com atenção no que diz respeito às causas ambientais, por se tratar da ocupação de terras improdutivas, e concomitantemente a ela seu manejo e utilização enquanto meio de sobrevivência dos assentados.

No município de Campos dos Goytacazes a ocupação do MST se deu em 12 de abril de 1997, mais especificamente numa área que abrange aproximadamente cerca de 8.500 hectares que formavam o antigo complexo da Usina São João. Tal propriedade apresenta significativa importância em nível ecológico para a região, haja vista, a considerável quantidade de lagoas existentes na região bem como fragmentos de Mata Atlântica. A ocupação de terras no Zumbi dos Palmares incluiu trabalhadores das mais diversas origens e ocupações profissionais rurais e urbanas, que foram atraídos através de reuniões e orientações sobre procedimentos e condutas. Contudo, outros se agregaram ao acampamento nos dias iniciais, interessados em se obter um pedaço de terra. Uma série de entidades locais apoiou a ação, incluindo mesmo membros dos sindicatos, da Prefeitura Municipal, da Escola Técnica Federal e da UENF, que doaram mantimentos e bens de primeira necessidade em apoio aos acampados (FAO/INCRA, 1999).

O processo de desapropriação das terras da Usina São João foi concluído em outubro de 1997 pelo INCRA, e em novembro daquele mesmo ano foram cadastradas as famílias acampadas, os ex-funcionários da usina e as famílias já cadastradas no Sindicato dos Trabalhadores Rurais de São Francisco de Itabapoana para receber os lotes. Em dezembro de 1997, os trabalhadores acampados nos lotes que compõem o atual Núcleo I, iniciaram o processo de demarcação das terras. Em assembléia realizada em janeiro de 1998 os assentados decidiram pela divisão em grupos para ocupação total da área. Após o parcelamento, a maior parte dos assentados recebeu os primeiros créditos de instalação, inicialmente os créditos de alimentação (R\$ $400,00)$ e de fomento (R\$1.025,00) (FAO/INCRA, 1999).

\subsection{A água na transmissão de doenças}

O estado do abastecimento de água e saneamento nos países em desenvolvimento ainda é caótico (DIAS, 2000). Uma série de doenças pode estar associada à água, tanto em decorrência de sua contaminação por excretas humanas ou de outros animais, quanto pela presença de substâncias químicas nocivas à saúde humana.

Tradicionalmente, as doenças relacionadas com a água vêm sendo classificadas em dois grupos: doenças de transmissão hídrica e doenças de origem hídrica. Doenças de transmissão hídrica são aquelas em que a água atua como veículo do agente infeccioso. As doenças de origem hídrica são aquelas causadas por determinadas substâncias químicas, orgânicas ou inorgânicas, presentes na água em concentrações inadequadas, em geral superiores às especificadas nos padrões de água para consumo humano.

Foram realizados diversos estudos que evidenciaram que as fezes do homem e dos animais de sangue quente são riquíssimas em coliformes e que estas bactérias usualmente não existem em águas não poluídas. Alguns membros do grupo coliforme podem ocorrer, às vezes com relativa abundância, no solo e 
mesmo em plantas, mas, ainda assim, as águas não poluídas praticamente não apresentam estas bactérias (CETESB, 1996). Cerca de 95\% das bactérias do grupo coliforme, oriundas das fezes humanas e de outros animais, são Escherichia coli. Segundo a Organização Mundial de Saúde estão incluídos no grupo coliforme todos os bacilos gram-negativos, aeróbios ou anaeróbios facultativos, não formadores de esporos, oxidasenegativos, capazes de crescer na presença de sais biliares ou outros compostos ativos de superfície, com propriedades similares de inibição de crescimento e que fermentam a lactose com produção de aldeído, ácido e gás a $35^{\circ} \mathrm{C}$ em 24-48 horas (CETESB, 1996).

Podem ser incluídos como coliformes termotolerantes a E. coli e espécies dos gêneros Klebsiella e Enterobacter. Somente a E. coli tem presença garantida nas fezes humanas e de outros animais homeotérmicos. Essa presença é em torno de 96 a $99 \%$ dentre os coliformes e os demais gêneros participam com percentuais que variam entre 3 e $8 \%$ em fezes. Em função disto apenas a $E$. coli oferece condições de garantir maior ou menor evidência de impacto fecal em uma amostra, sendo considerado o mais específico indicador de contaminação fecal recente e de eventual presença de microrganismos patogênicos (BRASIL, 2004).

\section{OBJETIVOS}

O trabalho tem como foco principal a realização de levantamento da condição situacional dos moradores do Assentamento Zumbi dos Palmares acerca do saneamento básico e da percepção ambiental da comunidade em relação ao saneamento e aos recursos naturais, com intuito de buscar subsídios que possibilitem o estabelecimento de futuras medidas que proporcionem uma melhor interação entre saneamento básico, desenvolvimento sustentável e equilíbrio ecológico. Os seguintes objetivos específicos foram delineados:

1) Verificar a qualidade bacteriológica do aqüífero freático do assentamento;

2) Entender como são relacionadas a reforma agrária e a estruturação do saneamento básico, mediante possibilidade das condições presentes causarem efeito deletério à população local e ao ambiente;

3) Analisar a percepção ambiental dos assentados em relação às condições sanitárias e aos recursos naturais da região.

\section{MATERIAL E MÉTODOS}

\section{1. Área de estudo}

O Assentamento Zumbi dos Palmares fica localizado entre as coordenadas $21^{\circ} 32^{\prime}$ e $21^{\circ} 45^{\prime} \mathrm{S}$, e $41^{\circ}$ $11^{\prime}$ e $41^{\circ} 16^{\prime} \mathrm{O}$, pertencendo aos territórios dos municípios de Campos dos Goytacazes e São Francisco de Itabapoana (Figura 1), compreendendo o conjunto de fazendas que faziam parte da antiga usina sucroalcooleira São João: Jacarandá, São Gregório, Paraíso, Campelo, Santa Maria, Cajueiro, Bom Jesus, Penha e Santana. Abrange uma área de aproximadamente 8000 hectares e está subdividido em cinco núcleos.

O primeiro núcleo é denominado Zumbi 1, antigamente conhecido como Porto dos Bondes; o segundo núcleo é o Zumbi 2 (Jacarandá); o terceiro núcleo é o Zumbi 3 (São Gregório); o quarto núcleo é o Zumbi 4 (Campelo); e o quinto núcleo é o Zumbi 5 (Cajueiro). Ao todo são 506 lotes distribuídos pelo INCRA. A média do tamanho dos lotes é de 10 hectares (FAO/INCRA, 1999), comparável às áreas de outros lotes de Assentamentos do MST (CARVALHO, 2013). 


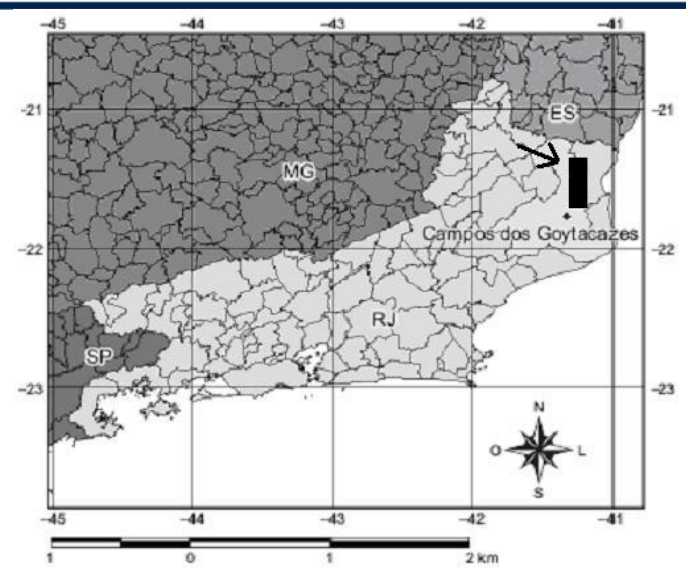

Figura 1 - Localização do Assentamento Zumbi dos Palmares

\subsection{Metodologia empregada}

A realização do trabalho se deu em duas fases distintas: a primeira foi referente à análise bacteriológica da água, e a segunda investigou condições sócio-econômicas, sanitárias e a percepção ambiental da população em relação ao saneamento básico.

\subsubsection{Análise bacteriológica da água}

A análise bacteriológica da água foi realizada no ano de 1999 na Universidade Estadual do Norte Fluminense (UENF), onde foram feitos exames bacteriológicos em amostras de água subterrânea de 24 poços localizados no Projeto de Assentamento Zumbi dos Palmares - cerca de 8.500 hectares, que formavam o complexo da antiga Usina São João.

As coletas foram realizadas entre o período de 16/03 a 19/05 daquele ano, com transporte fornecido pela UENF, cobrindo toda a área do até então Projeto de Assentamento, o qual apresentava-se subdividido pelos cinco núcleos acima descritos. Foram recolhidas, em média, 5 amostras por núcleo, oriundas de poços de aquíferos freáticos - o nível de água em seu interior coincide com o lençol, estando livre com sua superfície sob a ação da pressão atmosférica. Nos poços equipados com bombas, os primeiros jatos de água saídos foram desprezados por aproximadamente três minutos. Realizou-se a desinfecção da saída da bomba quando necessário, deixando escorrer novamente antes da coleta de amostras. A amostra foi coletada então em frascos devidamente esterilizados e armazenados em caixas térmicas até que chegassem ao laboratório. Em poços sem bombas, a amostragem foi feita diretamente no poço, com um recipiente esterilizado, logo abaixo da superfície, evitando a contaminação com a espuma ou com o material das paredes do poço (CETESB, 1996). A técnica utilizada para a determinação de coliformes foi a de tubos múltiplos, e todo o material utilizado nos procedimentos foram submetidos devidamente a processos de esterilização em autoclave (Cetesb, 1996).

\subsubsection{Investigação sanitária junto à população}

A segunda fase do trabalho foi realizada entre setembro de 2005 e fevereiro de 2006 e consistiu na realização de pesquisa de campo com um total de 100 famílias do Assentamento Zumbi dos Palmares, já então legalizados pelo INCRA, com composição subdividida em 20 famílias por cada núcleo do assentamento, compondo-se em 5 núcleos.

Para coleta de informações foi utilizado questionário composto por perguntas abertas e fechadas, aplicado a pessoas que se encontravam nos lotes dos respectivos assentamentos. O questionário compunha-se por questões relativas a saneamento básico, ao tempo de permanência do assentado no lote e à percepção ambiental dos assentados. Cada entrevista teve duração aproximada de 20 minutos. 
Os critérios aleatórios para a escolha dos lotes (local de amostragem) para realização das entrevistas foram os seguintes: a) de forma casual; b) por indicação feita pela equipe da CPT (Comissão Pastoral da Terra); c) por indicação feita por outros assentados. Para a análise dos resultados foram respeitadas as divisões do assentamento, previamente estabelecidas pelo INCRA, em Zumbi 1, Zumbi 2, Zumbi 3, Zumbi 4 e Zumbi 5.

\section{RESULTADOS}

\subsection{Análise bacteriológica}

$\mathrm{Na}$ totalidade das amostras analisadas foram encontrados índices elevados de coliformes totais (> 23,0 de coliformes totais em $100 \mathrm{~mL}$ da amostra). Verificou-se também a presença de Escherichia coli em $91 \%$ das amostras analisadas, ou seja, NMP superiores a 23,0 em $100 \mathrm{~mL}$, restando apenas duas amostras com valores iguais a $<1,1$ e 3,6 (NMP).

\subsection{Condição dos assentados}

Observa-se que a maioria dos assentados (entre 70 e $84 \%$ ) possui renda igual ou menor que 1 salário mínimo. Alguns casos apresentam de 1 a 2 salários evidenciados em maior número nos núcleos 3 e 4 ( 25 e $30 \%$ ), e pequena parcela apresentando faixas salariais superiores a 2 salários mínimos (Figura 2a).

Com referência ao tempo de residência no assentamento, constata-se que a maioria dos entrevistados pertence aos núcleos desde a sua fundação, seguido por famílias que estão no local há menos de três anos. Destaca-se o núcleo Zumbi 4 como aquele que comporta maior percentual $(90 \%)$ de famílias residentes desde a fundação do assentamento, seguido do núcleo 5, com $80 \%$. Os núcleos 1,2 e 3 apresentaram percentuais importantes com relação ao tempo de residência com menos de três anos, onde foram encontrados valores de 20 a $25 \%$ (Figura $2 b$ ).

A maioria dos assentados (de 44 a 70\%) apresenta como principal forma de obtenção de água o poço cacimba (Figura 2c). Formas alternativas como carro-pipa, poço da prefeitura ou até mesmo a compra da água, constituem-se em porcentagens bastante variadas, as quais obedecem a peculiaridades pertinentes a cada núcleo, como por exemplo a que se refere ao consumo através de poço da prefeitura, que atende somente aos moradores do núcleo Zumbi 3.

A Figura 2d mostra que em todos os núcleos do assentamento há utilização dos recursos hídricos para pesca e lazer apresentando-se maior incidência para pesca no Zumbi $3(43 \%)$ e menor no Zumbi 1 (13\%). O uso dos recursos hídricos para agricultura apresentou-se mais elevado no Zumbi 3 (18\%) e Zumbi 5 (19\%). As maiores porcentagens de não utilização destes recursos são apresentadas nos núcleos Zumbi 1, 2 e 4, variando de 48 a $63 \%$. Com relação ao uso doméstico verificaram-se porcentagens bem pequenas, variando de 4 a $6 \%$.

A utilização de pesticidas nos núcleos do assentamento apresenta variações que vão de 21 a $33 \%$. Quanto ao uso de adubo químico, os maiores índices foram encontrados no Zumbi 3 e 5. A utilização de adubo orgânico é maior nos núcleos 1 e 2 (38 a 39\%). Pequena parcela dos assentados se encontra sem lavoura (Figura 2e).

Podem ser percebidos elevados índices de respostas negativas com relação à interferência dos órgãos públicos junto ao assentamento no que se refere à restrição ao uso dos recursos ambientais da região. Observam-se valores importantes com referência à atuação contra o desmatamento, apresentando índice mais elevado no núcleo 5. Valores percentuais menores se reportaram à interferência com relação ao período do defeso pesqueiro e à orientação acerca das áreas de preservação. Restrições com relação ao uso de agrotóxico estão presentes com percentuais variando entre 5 e $21 \%$, ao contrário da adubação orgânica que apresentou somente 5\% (Figura 2f).

Constata-se que a maioria dos entrevistados visualiza como solução para a obtenção de água potável a construção de poço artesiano com rede de distribuição para atendimento à comunidade. Sugestões como tratamento no poço ou cacimba, bem como captação de água de chuva, apresentaram-se muito modestas. Apesar de se constituir em medida de caráter provisório, o carro pipa foi citado como possibilidade de obtenção de água, apresentando valores bastante pequenos, assim como tratamento no poço ou cacimba.

Persp. online: biol. \& saúde, Campos dos Goytacazes, 13 (4), 44-58, 2014 
A maioria dos entrevistados possui elevado grau de desconhecimento acerca de doenças transmitidas pela água, apresentando resposta negativa com relação à questão. No que se refere às respostas afirmativas houve destaque para o núcleo 2, o qual apresentou 11 respostas positivas, ao contrário do núcleo 4 que evidenciou o menor índice, com apenas 3 respostas afirmativas sobre o conhecimento de doenças transmitidas pela água (Figura $2 \mathrm{~g}$ ).

Com relação ao atendimento escolar observa-se que os núcleos 1 e 4 apresentam índices elevadíssimos de insatisfação. Os outros núcleos evidenciaram índices bem melhores, mas que se referem a escolas que oferecem apenas ensino de $1^{\mathrm{a}}$ a $4^{\mathrm{a}}$ série (Figura $2 \mathrm{~h}$ ).

A maioria dos assentados relata que nunca recebeu orientação em relação ao saneamento básico. A Tabela 1 mostra a distribuição de doenças relacionadas à água relatadas pelas famílias entrevistadas nos núcleos do assentamento. Ressalta-se que no questionário as referidas doenças eram opções dentre outras incluindo-se aquelas não veiculadas pela água. Através dela pode-se perceber que o Zumbi 4 apresenta menor número de citações em termos de doenças de veiculação hídrica, seguido pelo Zumbi 1. Os núcleos que mais apresentaram doenças relacionadas à água foram os Zumbi 2, 3 e 5.

Tabela 1 - Doenças relacionadas à água que os entrevistados da população dos núcleos do Assentamento relatam ter contraído. Cada número refere-se à quantidade de citações da referida doença por parte da população entrevistada.

\begin{tabular}{lccccc}
\hline Doenças & Zumbi 1 & Zumbi 2 & Zumbi 3 & Zumbi 4 & Zumbi 5 \\
\hline Verminose & 3 & 8 & 8 & 0 & 12 \\
Diarréia & 5 & 5 & 2 & 4 & 2 \\
Doença de pele & 6 & 6 & 6 & 4 & 7 \\
Escabiose & 0 & 3 & 4 & 4 & 3 \\
Coceiras & 5 & 6 & 8 & 0 & 4 \\
Total & 19 & 28 & 28 & 12 & 28 \\
\hline
\end{tabular}

\section{DISCUSSÃO}

\subsection{Análise bacteriológica da água}

Os resultados obtidos nos exames bacteriológicos das águas dos diversos poços localizados no Projeto de Assentamento Zumbi dos Palmares indicam que estas não satisfazem bacteriologicamente aos padrões de potabilidade para consumo humano, tanto para a Portaria 36, que vigorava na época em que foram realizadas as análises (BRASIL, 1990), quanto para a Portaria 518, atual (BRASIL, 2004). Ambas as Portarias determinam que coliformes fecais devem sempre estar ausentes na água potável, mas foram encontrados em $91 \%$ das amostras coletadas no Assentamento. A Portaria 36 determinava que em água não canalizada utilizada sem tratamento (poços, por exemplo), desde que não haja água de melhor qualidade, 95\% das amostras devem apresentar ausência de coliformes totais em $100 \mathrm{~mL}$. Esta foi atualizada pela Portaria 518, que determina que água para ser considerada potável não pode apresentar coliformes totais. De qualquer forma, em $100 \%$ das amostras analisadas foram encontrados coliformes totais, o que classifica as águas do Assentamento Zumbi dos Palmares como imprópria para consumo humano.

Durante a realização das coletas de amostra de água, foi verificado que os poços cacimbas utilizados no assentamento na época de sua implantação foram abertos pela própria população, sem o levantamento do perfil geológico e das condições do lençol aqüífero existente, como também ocorreu nos Assentamentos do MST localizados na região de Andradina-SP (CARVALHO, 2013). Fato este bastante compreensível, haja vista as precárias condições de vida da maioria de seus moradores e a ausência de infra-estrutura no que concerne ao atendimento das necessidades mínimas de saneamento e habitação. A abertura dos poços também não obedeceu às devidas recomendações sanitárias no que diz respeito à proteção deste recurso hídrico dos agentes poluidores, os quais deveriam ficar convenientemente afastados de instalações, estruturas e condutos que contenham ou veiculem líquidos contaminantes. 
Foram observadas diversas situações que podem contribuir, ou mesmo determinar o processo de contaminação dos poços do Assentamento Zumbi dos Palmares. Dentre os aspectos mais marcantes, podem ser citados: (i) proximidade dos poços com fossas sépticas, apresentando distâncias inferiores a 15 m, (ii) presença de animais domésticos nas proximidades dos poços, tais como porcos, galinhas, patos, cachorros, cabras, conforme também descrito por Carvalho (2013) para outros Assentamentos do MST, (iii) presença de poços desprotegidos, sem coberturas ou revestimentos, ocasionando a presença de larvas de mosquitos e insetos, e (iv) presença de valas abertas em terrenos acidentados apresentando animais e lixo nas proximidades dos poços.

\subsection{Sobre a pesquisa de campo}

Por meio de uma parceria com a CPT (Comissão Pastoral da Terra) durante o processo de coleta de dados, esta divulgava também seus projetos e colhia resultados a partir do que fora anteriormente implementado. Outra parceria de fundamental importância foi a estabelecida com alguns assentados, que se dispuseram a acompanhar a pesquisadora para o trabalho. Tais sinergias foram bastante produtivas para ambas as partes envolvidas.

Desde a formação do Assentamento Zumbi dos Palmares, a questão da assistência técnica aos assentados é uma atividade, em tese planificada e estabelecida pelo INCRA, através do (PDA) e que tem sido feita de forma deficiente por causa da insuficiência da disponibilidade de técnicos capazes de atender a todas as demandas existentes" (ZINGA, 2004). A renda familiar é notoriamente comprometida frente às dificuldades encontradas no processo de implementação das atividades agropecuárias. Problemas como falta de irrigação - relatado por muitos assentados tanto pela dificuldade de captação de água quanto pela qualidade da água "muito salobra" - assim como falta de máquina para preparação do solo o qual muitas vezes se encontra impróprio para agricultura, consistem em fatores que podem responder aos elevados índices de baixos salários.

A dificuldade de escoamento dos produtos do assentamento é outro agravante no que se refere à questão da baixa renda. Casos como perda de lavouras inteiras foram relatados, assim como especulação de alguns compradores que ofereciam preços muito baixos pelos produtos. Outro fator mencionado e de relevante importância consiste na precariedade das estradas de acesso aos lotes que se localizam fora das imediações do asfaltamento principal dificultando ainda mais a saída dos produtos para comercialização. Como tentativa de solução para o problema, realiza-se a comercialização dos produtos através de uma "feira da roça" que acontece todas as sextas-feiras em pequena praça pública na Av. Dom Bosco, e que consegue atender a uma pequena parte de assentados interessados. Outro relato importante entre os assentados foi sobre a necessidade de se complementar renda exercendo outras atividades, através de inúmeros serviços informais, atuando como pedreiros, pescadores, costureiras, balconistas, dentre outros. O trabalho agrícola para grande parte dos assentados tem como objetivo além da subsistência familiar, cumprir o pagamento dos projetos realizados pelo INCRA, como o crédito do PRONAF. Apesar das dificuldades encontradas, muitos lotes apresentam um bom processo agrícola desenvolvendo atividades como plantio de cana-de-açúcar, árvores frutíferas, feijão, criação de gado bovino, aves e caprinos. 


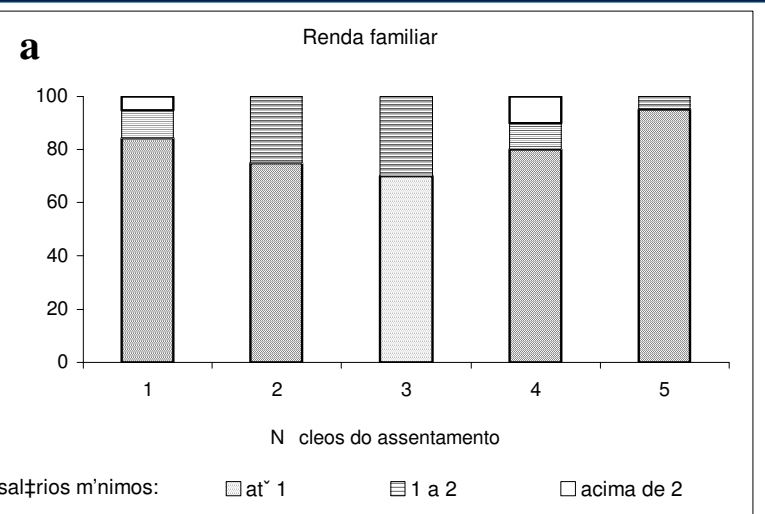

b

Tempo de resid $\square$ ncia no assentamento

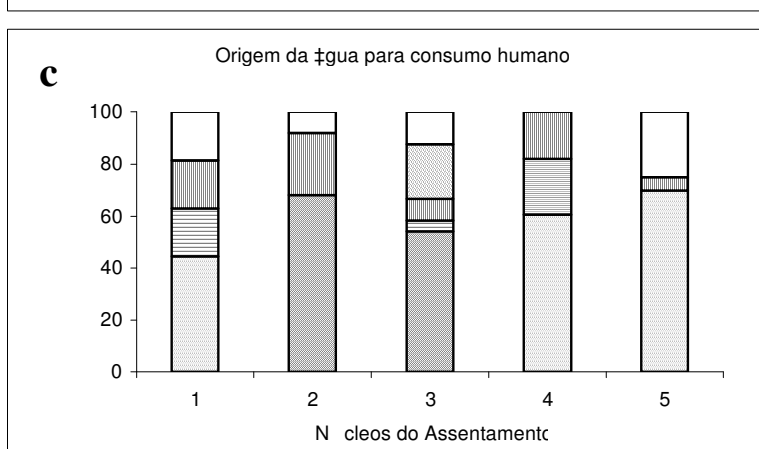

$\square$ Po"o dom`stico $\square$ Carro-pipa $\square$ Comprada $\square$ Po"o da prefeitura $\square$ Outros

b

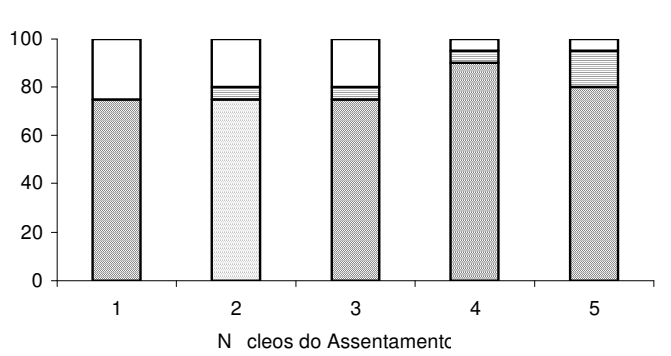

$\square$ desde a funda"`o $\quad$ 其mais de 3 anos $\square$ menos de 3 anos
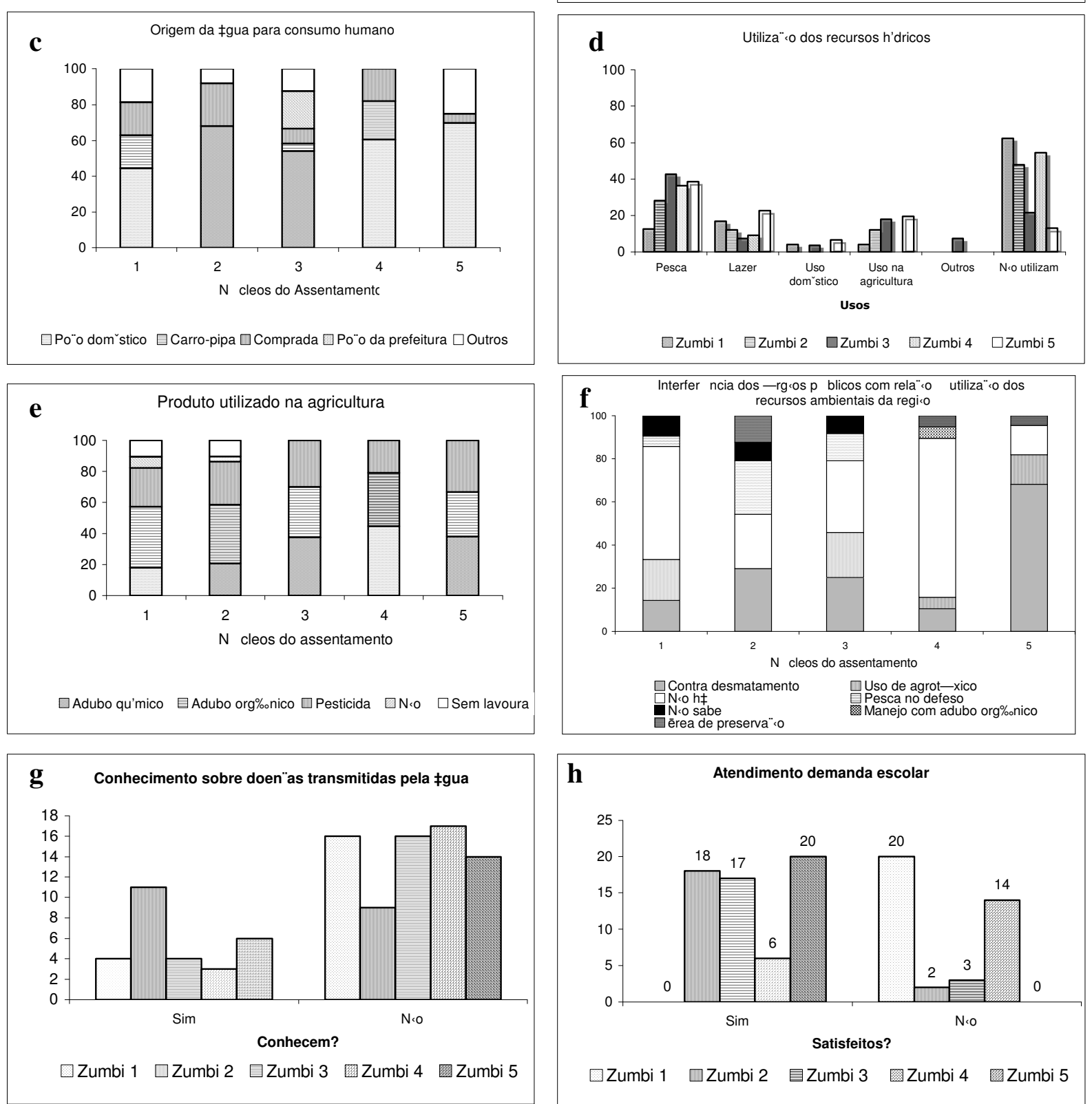

Figura 2 - Variáveis acessadas junto aos cinco núcleos do Assentamento Rural Zumbi dos Palmares: (a) Renda familiar; (b) Tempo de residência dos assentados no local; (c) Origem da água para consumo humano; (d) Forma de utilização dos recursos hídricos da região; (e) Produtos utilizados na agricultura; (f) Tipos de interferência dos órgãos públicos com relação à utilização dos recursos ambientais da região; (g) Estado de conhecimento sobre as doenças transmitidas pela água; (h) Satisfação em relação ao atendimento da demanda escolar. 
O uso de pesticidas e adubos químicos constitui-se em uma constante nos diversos núcleos do assentamento. Foi relatado pelos assentados da maioria dos núcleos que a necessidade do uso de tal produto fundamenta-se no enfrentamento de problemas sérios com relação a pragas no desenvolvimento de culturas como coco, maracujá, abacaxi, cujo plantio se dá principalmente nos núcleos 4 e 5 . Apesar da freqüente utilização destes produtos nos processos agrícolas do assentamento reconhece-se algum ganho ecológico diante do uso da adubação orgânica na região, a qual se dá a partir do uso de esterco de boi. Pode-se perceber, no entanto, uma forte tendência à agricultura do tipo convencional, a qual segundo relatos faz-se necessária em função do problema das pragas, como citado anteriormente, ou mesmo pela ausência de outras formas de manejo com a terra. A CPT realiza um trabalho informativo com respeito à homeopatia nos processos agrícolas, na tentativa de oferecer possibilidades alternativas. O trabalho ainda é lento e difícil e apresenta resistência por grande parte dos assentados.

A disponibilidade de mão de obra qualificada e a assistência técnica encontram-se, portanto, intimamente ligadas ao sucesso do pequeno agricultor nos assentamentos estabelecidos. A má qualidade de assistência técnica leva frequentemente à diminuição da pequena produção agropecuária existente, favorecendo baixos rendimentos ou mesmo a desistência do lote. A possibilidade de implementação de programas ou projetos que viabilizem intervenção nos assentamentos rurais numa perspectiva social, econômica e ambiental, passa, portanto, pelo cumprimento do que fora proposto desde o início no projeto de assentamento e que visivelmente fica a desejar como observado nos resultados.

Com relação ao tempo de residência no lote, foi observado que a maioria é residente desde a fundação do assentamento. Alguns dos fatores relatados com relação à desistência dos lotes se remetem a questões pertinentes à infra-estrutura do assentamento tais como carência de postos de saúde, transporte, creche, saneamento básico e concomitante falta de água potável, escolas em nível de $5^{\mathrm{a}}$ a $8^{\mathrm{a}}$ séries e ensino médio, falta de orientação técnica no que se refere aos trabalhos agropecuários e a falta de condições para as famílias se auto-sustentarem também foram relatados.

Dentre os aspectos relativos à infra-estrutura do assentamento, relacionadas ao saneamento básico, pode-se perceber que este estrutura-se fundamentalmente a partir de poço cacimba e da fossa domiciliar. A coleta do lixo ocorre apenas nas imediações da estrada principal ou nas localidades circunvizinhas, como também é o caso na quase totalidade dos Assentamentos no noroeste do Estado de São Paulo (CARVALHO, 2013). Observa-se que o poço cacimba foi a principal forma de obtenção de água para consumo humano. Não foi mencionado pelos assentados qualquer tipo de tratamento nestes poços, entendendo-se assim que a água é captada e utilizada in natura. A maioria dos moradores dos Assentamentos estudados por Carvalho (2013) também relata que utiliza a água sem tratamento prévio qualquer (67\%), mas $32 \%$ ou fervem ou cloram a água.

Como abordado anteriormente foram realizadas análises provenientes de 24 poços do até então projeto de assentamento as quais evidenciaram presença de coliformes totais em $100 \%$ das amostras, o que torna a água destes mananciais imprópria para consumo humano. O assentamento conta hoje com um grande número de poços subterrâneos, os quais deveriam ser devidamente analisados antes de sua utilização. Entretanto, a presença de resultados insatisfatórios encontrados nas análises mencionadas pressupõe a necessidade de uma melhor investigação com relação à potabilidade da água utilizada pela comunidade do assentamento, a fim de se verificar se o local apresenta comprometimento do aqüífero freático ou se o problema se dá a partir de outras formas de contaminação como, por exemplo, a maneira com a qual se deu a abertura do poço. Com relação ao tipo de esgotamento sanitário, todos apresentaram a fossa séptica como forma de esgotamento doméstico, com exceção de um assentado (Zumbi 4) que respondeu ter esgoto a céu aberto.

Dentre as doenças de maior freqüência relatadas pelos assentados e que apresentam estreita relação com a questão do saneamento básico, destacam-se verminoses, diarréia, doenças na pele, coceiras. O Zumbi 4 apresenta um posto de saúde público em suas imediações, o que possivelmente contribuiu para a ocorrência de um número menor de casos de doenças relacionadas à água, conforme relatado pela população. O Zumbi 1 apresenta-se como o mais próximo à cidade, o que contribui para a detecção de um número intermediário de doenças relatadas. Em contrapartida, os Zumbi 2, 3 e 5 apresentaram os maiores números de doenças, o que está relacionado à falta de postos de saúde, bem como à distância destes núcleos em relação à cidade.

Alguns núcleos apresentam peculiaridades bastante distintas, a exemplo destacamos a que se refere ao consumo de água através de poço da prefeitura. O poço mencionado atende somente aos moradores da

Persp. online: biol. \& saúde, Campos dos Goytacazes, 13 (4), 44-58, 2014 
localidade de Santa Ana, os quais são assentados que não são residentes dos seus lotes - localizados no Zumbi 3. Nas adjacências do Assentamento existem duas unidades de abastecimento que ficam localizados próximos aos núcleos Zumbi 3 e ao Zumbi 2, e que têm o objetivo de atender as localidades de Santa Ana e Mundéus respectivamente. Ambos os sistemas compõem-se de uma caixa de 10.000 litros que abastece respectivamente a cada localidade. Conta com a tubulação na rede de distribuição de $\varnothing=75 \mathrm{~mm}$, e nas residências é reduzido para $3 / 4$ polegada. O sistema funciona a partir de uma bomba submersa no poço que é acionada quando o nível da água diminui, então através da bóia o disjuntor é acionado automaticamente para reabastecimento da caixa, que distribui a água às localidades por gravidade. Os sistemas não contam com etapas de cloração nem filtração, possuindo, no entanto, monitoramento da FUNDENOR, a qual emite um laudo técnico acerca da qualidade da água.

Outro ponto importante é que a maioria relata que nunca recebeu orientação no que diz respeito a informações sobre saneamento básico. Pequeno número de pessoas entrevistadas apresentou resposta positiva quanto a este item onde podemos destacar algumas instituições que foram mencionadas e que estariam envolvidas neste processo, como CPT, UENF, CCZ, INCRA e EMATER. Em virtude disto, duas possibilidades podem ser consideradas: a orientação oferecida por estas instituições não atinge a grande parcela dos assentados ou não há diretrizes efetivas com relação à orientação ou implementação de projetos acerca de saneamento na área estudada, constituindo-se as porcentagens afirmativas em casos isolados. É importante mencionar que o saneamento dentre diversas outras metas já se configurava em proposta do Plano de Desenvolvimento do Assentamento Zumbi dos Palmares elaborado pela FAO/INCRA (1999), como política destinada ao processo de implementação do assentamento.

No município de Campos dos Goytacazes, o PA Zumbi dos Palmares contou por três anos com o apoio da equipe do projeto LUMIAR, cuja responsabilidade foi proporcionar assistência técnica e organizacional às famílias assentadas, bem como o estabelecimento de Programa de Desenvolvimento Sustentável. Todas as ações planejadas por essa equipe fizeram parte do PDA (FAO/INCRA, 1999). Segundo Peixoto et al. (2000), a implantação do Projeto LUMIAR no Estado do Rio de Janeiro teve como ponto principal de ação a intervenção direta das equipes junto dos assentamentos rurais selecionados dentro do projeto. Neste sentido, o PROCERA - Programa de Crédito Especial para a Reforma Agrária, (substituído em 1999 pelo Programa Nacional de Fortalecimento da Agricultura Familiar - PRONAF) e o Projeto LUMIAR foram implementados pela constituição de equipes locais que deveriam atender aos assentamentos. No entanto, o projeto LUMIAR também foi desativado e atualmente o INCRA está tentando executar um processo de descentralização da Reforma Agrária, que deverá ficar a cargo das municipalidades.

A desinformação com relação às doenças transmitidas e/ou veiculadas pela água é alarmante, onde podemos visualizar que este tipo de conhecimento apresenta-se distante da cultura do assentado. Segundo Zinga (2004) a maioria (60\%) dos assentados apresenta grau de escolaridade de $1^{\text {a }}$ a $4^{\text {a }}$ série e $19 \%$ apresentam escolaridade de $5^{\mathrm{a}}$ a $8^{\mathrm{a}}$ série, compreendendo, portanto, que grande parcela dos assentados possui apenas o ensino fundamental. Constata-se ainda que $18 \%$ dos entrevistados são analfabetos (ZINGA, 2004).

No que se refere ao atendimento à demanda escolar, com exceção dos núcleos 1 e 4 foi constatado que boa parte dos entrevistados o considera satisfatório. No entanto, alguns aspectos devem ser relevados nesta questão. Em primeiro lugar, a região apresenta escolas que oferecem apenas ensino de $1^{a}$ a $4^{a}$ séries, atendendo em média crianças de até 12 anos aproximadamente. Portanto, se o entrevistado se configura em adulto que não se interessa em estudar e nem apresenta em sua residência alguém que tenha este desejo, a presença da escola pode gerar resposta afirmativa somente pelo fato de ela existir. Em segundo lugar, foi observado que a instituição "escola" está associada a crianças ou adolescentes, e com relação aos últimos houve grande reclamação sobre a falta de escolas em séries mais adiantadas. Foi relatado que a possibilidade de estudos posteriores a $4^{\mathrm{a}}$ série se apresentam nas localidades de Travessão de Campos ou em Campos dos Goytacazes, ambas de difícil acesso em virtude da deficiência de transporte público.

A falta de acesso a informações tanto no que se refere às doenças transmitidas pela água, ou mesmo a qualquer assunto que venha a contribuir para o alcance de melhor qualidade de vida dos assentados, apresenta laços estreitos com relação ao baixo grau de escolaridade, ao deficitário atendimento da demanda escolar, bem como à falta de implementação de programas de capacitação e assistência técnica, os quais viabilizariam conhecimento à comunidade assentada.

Apesar dos resultados pertinentes às questões referentes ao saneamento se apresentarem insatisfatórios, as perguntas que solicitaram sugestões para obtenção de água potável para o assentamento evidenciaram algum conhecimento por parte dos assentados com relação ao assunto. A maioria respondeu 
que a construção de um poço artesiano comunitário com a colocação de rede de distribuição seria uma boa alternativa para solução do problema da potabilidade da água existente no local. A captação de água de chuva apresentou-se como resposta em alguns núcleos, mas com resultados muito tímidos. A CPT iniciou implementação de um projeto que visa o aproveitamento das águas de chuva com intuito de solucionar ou diminuir o problema da falta de água potável no assentamento. Já foram construídas duas cisternas com esse objetivo, a fim de se fazer uma avaliação inicial acerca da utilização e manejo deste tipo de sistema no meio rural. Foi relatado que o atendimento com carro-pipa pela Prefeitura Municipal de Campos, além de ter caráter provisório, se dá de forma esporádica, apresentando-se, portanto, como uma medida bastante insatisfatória no que tange a este tipo de problema.

A proximidade dos lotes com os mananciais hídricos da região propicia a utilização dessas águas nos núcleos, tendo portando significativa ligação com seu uso na agricultura, pesca e consumo doméstico. Em muitos casos há um deslocamento dos indivíduos para realização de atividades como pesca e lazer em virtude da inexistência de mananciais para tais fins no núcleo que abriga seu lote ou em área vizinha. Mesmo assim estas duas atividades se encontram presentes nas respostas de todos os núcleos. Um dos moradores do Núcleo 5 relatou que durante certo período fora pescador e que é freqüente o uso da pescaria para satisfação das necessidades de muitos assentados com relação à alimentação.

Segundo relatório referente ao PDA, enquanto terras da Usina São João, havia um complexo sistema de irrigação que iniciava-se a partir de captação no rio Paraíba do Sul, fluía por gravidade ao longo do canal do Vigário, havendo pontos de captação para o Núcleo 1, formava uma bacia no Porto dos Bondes, de onde seguia para a lagoa do Campelo. Do Ponto dos Bondes a água era recalcada, inicialmente em tubos pressurizados e depois por canais abertos e por gravidade à lagoa do Jacarandá, o mesmo ocorrendo daí até a lagoa de São Gregório. Além de água, a Usina utilizava os canais para ferti-irrigação com vinhoto, subproduto da industrialização da cana-de-açúcar, assim como água de lavagem das instalações industriais (FAO/INCRA, 1999).

A dificuldade para irrigação foi uma das reclamações mais evidentes por parte dos assentados, onde foram relatadas perdas consideráveis nas lavouras tanto pela questão da escassez da água quanto pela qualidade da água, a qual segundo relatos é extremamente salobra. A realização de irrigação nas lavouras se dá através de captação por bombeamento, o qual envolve consumo de energia elétrica assim como uma boa estrutura de encanamentos. A questão da irrigação está condicionada, portanto, às condições sócioeconômicas do assentado.

A pecuária é outro tipo de atividade exercida no assentamento que relaciona-se à utilização de recursos hídricos mesmo que em proporções consideravelmente menores quando comparada à agricultura. Esta é uma das atividades que aos poucos vai ganhando preferência entre os assentados no Zumbi dos Palmares, com várias famílias possuindo pelo menos uma vaca leiteira, o que possibilita a obtenção de renda diária através da venda de leite e queijo (ZINGA, 2004).

Com relação à interferência dos órgãos públicos na utilização dos recursos ambientais da região, constatam-se relevantes resultados quando questionado sobre as restrições no manejo dos mesmos, pois muitos responderam "não sabem" ou "não têm restrições", o que evidencia desinformação com relação ao assunto. A própria implantação do projeto de assentamento apresentou problemas com relação à delimitação dos lotes em áreas de preservação permanente evidenciando assim ou desconhecimento ou negligência no que tange ao cumprimento de leis de preservação ambiental. A visualização de áreas de preservação pelos assentados, seja com relação a lagoas ou resquícios de mata, se refere em especial ao respeito à época do defeso, e à proibição do desmatamento, realizados pelo IBAMA em suas inspeções. Muitos assentados responderam que não utilizam os recursos hídricos da região, o que pode estar relacionado à distância dos lotes em relação aos mananciais e, principalmente, à falta de um programa de Educação Ambiental direcionado à população local.

Segundo AQUINO (2006), os defensivos agrícolas utilizados no Assentamento Zumbi dos Palmares englobam uma ampla gama de tipos de agrotóxicos, que se destinam a combater ervas daninhas, fungos e insetos. Foi observada alguma orientação com relação ao uso de agrotóxico nas lavouras do assentamento. Segundo alguns assentados a não utilização deste produto acarreta perdas consideráveis em decorrência de pragas, assim como o uso do adubo químico apresenta resultados mais rápidos sendo então comercialmente mais atraente. Reiterando informações anteriores foi observada carência de assistência técnica junto aos assentados, distanciando assim a possibilidade de se trabalhar formas alternativas como reaproveitamento de lixo orgânico doméstico, rochas moídas, cinzas, etc., bem como alternativas mais ecológicas de manejo tais como rotação de culturas, coberturas vivas e mortas, cultivo em curva de nível ou plantio direto. 
A CPT desenvolve trabalho sobre a utilização de homeopatia nos processos agrícolas, o qual segundo concepção da Universidade Federal de Viçosa, consiste em "método de impacto com resultado comprovado que soluciona o problema social do uso racional/ecológico na terra quanto à produção de alimentos saudáveis, respeitando a biodiversidade e dispensando os agrotóxicos das propriedades rurais" (CASALI, 2004). Entretanto, a adesão dos assentados apresenta-se difícil, assim como a divulgação do trabalho. Observa-se no assentamento uma naturalização com relação ao uso de agrotóxicos que ora são concebidos como veneno ora como remédio.

\section{CONCLUSÕES}

Pode-se perceber que imbuído ao processo de implementação do assentamento está a necessidade iminente de informações que abarquem a temática ambiental, a partir das quais possam ser refletidas as diversas mudanças ocorridas nos ecossistemas locais. Neste sentido tanto as propostas de plano de desenvolvimento do assentamento (PDA) elaborados pelo INCRA, quanto dos demais órgãos ligados ao projeto de reforma agrária como EMATER e Prefeitura, devem buscar a identificação de princípios ambientais a fim de se conseguir compatibilizar desenvolvimento rural sustentável e conservação ambiental.

No processo de implementação do Assentamento Zumbi dos Palmares a questão pertinente à estruturação do saneamento básico de um modo geral ficou a cargo dos próprios assentados não atendendo ao que reza o conceito de saneamento básico segundo a Organização Mundial de Saúde, que tem por definição o controle de todos os fatores do meio físico do homem, que exercem ou podem exercer efeito deletério, sobre seu bem estar físico, mental ou social. Há necessidade de se realizar estudo aprofundado sobre a qualidade da água local em função do que fora encontrado nos resultados referentes aos exames bacteriológicos realizados no ano de 1999.

Não foi observada a implementação de projetos de Educação Ambiental junto aos assentados, ao contrário, houve uma grande reclamação com referência ao abandono e descaso por parte dos órgãos públicos com relação aos problemas de infra-estrutura enfrentados no assentamento, destacando-se o saneamento básico, assistência técnica e atendimento à demanda escolar. Ademais, os assentados dizem não utilizar os recursos hídricos da região e somente serem informados em relação às questões ambientais em momentos de inspeção ou orientação a respeito de cumprimento de legislação ambiental.

A avaliação da percepção ambiental acerca dos recursos naturais existentes na região, bem como a relevância de parâmetros como tradições e valores culturais ainda não são incluídos nos programas educacionais e nas investigações realizadas no local. Além disso, tanto os PCNs quanto a Lei 9.795/99, que dispõe sobre a Educação Ambiental e institui a Política Nacional de Educação Ambiental, incentivam a abordagem articulada das questões ambientais locais, regionais, nacionais e globais, além de apoiarem iniciativas a experiências locais e regionais. Tais atividades fomentam, assim, a regionalização do conhecimento visando um aprendizado participativo e relacionado às necessidades da região.

\section{REFERÊNCIAS BIBLIOGRÁFICAS}

AQUINO, S. L. Um estudo sobre os impactos socioambientais do uso de agrotóxicos em três assentamentos de reforma agrária no município de Campos dos Goytacazes, RJ. Monografia de Bacharelado, Universidade Estadual do Norte Fluminense - UENF, 2006.

BRASIL, Ministério da Saúde. Portaria nº 36. Padrões de Potabilidade da Água, 19/01/1990.

BRASIL, Ministério da Saúde. Portaria no 518. Padrões de Potabilidade da Água, 25/03/2004.

CARVALHO, L. H. As condições de vida dos assentados da região de Andradina: a realidade e os indicadores de avaliação da política pública de reforma agrária. Tese de Doutorado em Serviço Social, Universidade Estadual Paulista - UNESP, 2013. 
CASALI, C. W. D. Uso da homeopatia na agricultura: Tecnologia Social (on line), 2004. Disponível em: $<$ http://www.homeopatias.com/jornal>. Acessado em 2005.

CETESB. Técnicas de Análises Bacteriológicas da Água: Tubos Múltiplos. São Paulo, 1996.

FAO/INCRA. Proposta de Plano de Desenvolvimento do Assentamento Zumbi dos Palmares. Rio de Janeiro, 1999.

DIAS, G. F. Educação Ambiental - princípios e práticas. 6 ed. São Paulo: Gaia, 2000.

GEHLEN, I. Uma estratégia camponesa de conquista da terra: o caso da fazenda Sarandi. Dissertação de mestrado. Universidade Federal do Rio Grande do Sul. 1983.

GONÇALVES, C. U. Capelinha: marco e marcas da luta pela terra no Rio de Janeiro. Vértices, v.6, n.2, p.83-102, 2004.

INSTRUÇÃO NORMATIVA INCRA Nº15, DE 30 DE MARÇO DE 2004 (2004) Disponível em: $<$ www.incra.gov.br>. Acessado em 2014.

NOVAES, R. Reforma Agrária. Debate: a reforma agrária hoje. Estudos Sociedade e Agricultura, n.6, p. 535, 1996.

PEIXOTO, M. GERMANO, I., TOMAZ, N. Organização Social dos Assentados e o Projeto LUMIAR: A Ação das Equipes Locais nos Assentamentos. Anais do X Congresso Internacional de Sociologia Rural. Rio de Janeiro, 21p, 2000.

ZINGA, M. R. M. Um estudo de caso sobre as causas da permanência e desistência no assentamento Zumbi dos Palmares. Dissertação de Mestrado. Universidade Estadual do Norte Fluminense - UENF, Campos dos Goytacazes/RJ, 2004. 